\title{
Article
}

\section{Thermo-Chemical Treatment for Carcass Disposal and the Application of Treated Carcass as Compost}

\author{
Jae-In Lee ${ }^{1}$, Eun-Ji Cho ${ }^{2}$, Fritz Ndumbe Lyonga ${ }^{3}$, Chang-Hee Lee ${ }^{4}$, Sue-Yun Hwang ${ }^{5}$, Dock-Hwan Kim ${ }^{6}$, \\ Chang-Gu Lee ${ }^{7}$ and Seong-Jik Park ${ }^{2, *}$ \\ 1 Department of Integrated Systems Engineering, Hankyong National University, Anseong 17579, Korea; \\ 2020570102@hknu.ac.kr \\ 2 Department of Bioresources and Rural System Engineering, Hankyong National University, \\ Anseong 17579, Korea; diction007@hknu.ac.kr \\ 3 Department of Chemical Engineering, Hankyong National University, Anseong 17579, Korea; \\ fritznlyonga@hknu.ac.kr \\ 4 Department of Horticulture Life Sciences, Hankyong National University, Anseong 17579, Korea; \\ changheelee@hknu.ac.kr \\ 5 Department of Chemical Engineering, School of Food Biotechnology and Chemical Engineering, \\ Hankyong National University, Anseong 17579, Korea; dutuya@hknu.ac.kr \\ 6 Neul Purungil Corporation, Buyeo 33144, Korea; neul888@naver.com \\ 7 Department of Environmental and Safety Engineering, Ajou University, Suwon 16499, Korea; \\ changgu@ajou.ac.kr \\ * Correspondence: parkseongik@hknu.ac.kr; Fax: +82-31-670-5139
}

Citation: Lee, J.-I.; Cho, E.-J.; Lyonga, F.N.; Lee, C.-H.; Hwang, S.-Y.; Kim,

D.-H.; Lee, C.-G.; Park, S.-J.

Thermo-Chemical Treatment for Carcass Disposal and the Application of Treated Carcass as Compost. Appl. Sci. 2021, 11, 431. https://doi.org/ 10.3390/app11010431

Received: 4 December 2020 Accepted: 31 December 2020 Published: 4 January 2021

Publisher's Note: MDPI stays neutral with regard to jurisdictional clai$\mathrm{ms}$ in published maps and institutional affiliations.

Copyright: (C) 2021 by the authors. Licensee MDPI, Basel, Switzerland. This article is an open access article distributed under the terms and conditions of the Creative Commons Attribution (CC BY) license (https:// creativecommons.org/licenses/by/ $4.0 /)$.

\begin{abstract}
A mechanized thermo-chemical treatment system was developed to treat the undecomposed carcass and remediate livestock burial sites. Animal carcasses were thus processed via crushing, mixing, and treatment with quicklime treatment, heat treatment $\left(200-500{ }^{\circ} \mathrm{C}\right)$, and mixing with sawdust. The machinery was applied to two sites where 16,000 chickens and 418 pigs had previously been buried in fiber-reinforced plastic storage bins. No dioxins were detected in the gas discharged during processing, and the concentration of total volatile organic compound, toluene, ethylbenzene, xylene, and styrene were $430.3,139.0,18.3,21.4$, and $10.4 \mu \mathrm{g} / \mathrm{m}^{3}$, respectively, which were below the air pollutant emission standards issued by the Korean Ministry of Environment. Korean standards stipulating the use of treated carcasses as compost (,$N$, and P content, heavy metal concentration, Escherichia coli, and Salmonella) were met, but the germination index value was less than 70 , not satisfying the criteria. Plant height, leaf length, leaf width, and dry weight of lettuce grown in soil amended with treated carcass product were significantly lower than those grown in low nutrient soil due to the poor germination index of the treated carcass. These results indicate that a composting process is required before the use of the treated carcass as a fertilizer. The addition of zeolite retarded the elution of ammonia from the carcasses and its efficiency was about $87.9 \%$. It is expected that the mechanized thermo-chemical treatment process developed in this study could replace other technologies for the remediation of livestock burial sites.
\end{abstract}

Keywords: carcass disposal; animal disease; thermo-chemical treatment; plant growth; compost; quicklime

\section{Introduction}

Large numbers of livestock are raised in intensive industrial livestock production systems in Korea to supplement the population's dietary protein [1]. In 2010, domestic livestock production was valued at 15.5 trillion Korean Republic won (KRW), exceeding the 9.5 trillion KRW value of rice production. Livestock production is an important industry that accounts for $34.4 \%$ of the total national agricultural and forestry production [2]. Breeding livestock numbers have been steadily increasing in recent years owing to the intensive and large-scale growth of the livestock industry. However, mass mortality 
of livestock frequently results from unforeseen outbreaks of infectious diseases. Socioeconomic impacts have been increasing in Korea owing to infectious diseases such as footand-mouth disease, avian influenza, brucellosis, and African swine fever [3,4]. Particularly serious economic losses of about 3 trillion KRW occurred in 2011 owing to the outbreak of foot-and-mouth disease [2].

Disposal methods including burial, composting, incineration, alkaline hydrolysis, and rendering are processes commonly employed to deal with carcass disposal following a mortality event [5]. The burial process entails the disposal of animal carcasses through the excavation of a trench or ditch and subsequent backfilling of soil [6]. Benefits include low cost, convenience, availability of necessary equipment, simple logistics, and low technical requirements. Furthermore, the method is time-efficient considering daily mortalities [7]. Despite logistical and economic advantages, concerns about potential effects on public health and environment have resulted in a less favorable perception of this method [8]. This disposal method has been banned in many locations including within the European Union since infectious diseases may inadvertently affect other organisms in the food chain and can contribute to environmental hazards [9]. Glanville [10] observed that the inadequate burial of livestock can result in serious problems owing to the rapid breakdown of the animal carcasses. The area within 1-2 $\mathrm{m}$ from burial sites can be infected and areas with high water tables can be severely impacted by raised concentrations of nitrates, chlorides, ammonia, and fecal pathogens [11].

In Korea, livestock carcasses killed as per the "Livestock Infectious Disease Prevention Act" are required to be promptly incinerated or buried; however, incineration and other safe carcass disposal methods are often impractical for domestic livestock owing to the shortage of suitable facilities [12]. Approximately 5000 livestock burial sites were established in 2011 following several foot-and-mouth disease outbreaks in 2010. Since most burial methods that are currently used for disposal of animal carcasses are rapidly implemented near the breeding facilities, there has been insufficient consideration given to the location of burial sites (including environmental factors); there has also been inadequate follow-up management. Thus, there are risks of contamination of soil by pathogens and secondary leachate from the burial of carcasses. Unsatisfactory disposal of livestock following mortalities may generate environmental and health hazards such as odor nuisance, contamination of groundwater by leachate, and exposure to hazards from microorganisms and viruses [13,14]. Further, despite buried carcasses not being completely decomposed, many farmers proceed with cultivating crops in these areas. According to actual monitoring of burials by the Korean Ministry of Environment, about 70\% of burials constructed by the outbreaks of FMD/AI were reported a low decomposition rate even after two years of burying [4]. McClaskey [15] also reported that the decomposition process of buried carcasses generally requires 5-10 years, although even after several years, carcasses in large-scale burials do not undergo significant decay except for the loss of body fluid.

In order to treat the undecomposed carcass in burial sites, several techniques including compost, rendering, incineration, and alkaline hydrolysis have been applied [3]. Composting of animal carcasses has advantages including the production of valuable by-products, versatility, ease of handling, and the destruction of pathogens by heat during the production process [16], but major disadvantages of carcass composting methods include the long processing time before the compost is mature, production of nuisance odors and greenhouse gases such as $\mathrm{CO}_{2}$, and insects such as flies may invade the composting area [7]. Rendering of animal carcasses involves their conversion into three end products using mechanical processes (e.g., grinding, mixing, pressing, decanting, and separating), thermal processes (e.g., cooking, evaporating, and drying), and sometimes chemical processes (e.g., solvent extraction). The end products are carcass meal (proteinaceous solids), melted fat or tallow, and water [17]. The benefits of rendering are that it provides a source of proteins for use in animal feed formulations and provides a hygienic means of disposing of fallen and condemned animals. However, a shortcoming of the technique includes the need for animal carcasses to be transported from the farm to a rendering plant. Because the 
carcasses will be removed from the infected premises, there are significant biosecurity risks with adverse effects being the by-product wastewater production [18]. Large amounts of energy are consumed to generate the required high temperatures and pressure. This also necessitates the use of specialized equipment and personnel [7]. Incineration is the process where animal carcasses or by-products are turned to inorganic ash by being burnt at high temperatures $\left(>850{ }^{\circ} \mathrm{C}\right)$ which enables to kill the pathogens in the animal carcass [19]. The production of gaseous emissions from burning of wood or fossil fuels is the principal concern. Metal concentrations in the flue gas have also been found to be higher in animal carcass incinerators than in medical incinerators [20]. Other health issues arising from incineration include the release of dioxins and furans from flue gas and fly ash; these can enter the food chain through grazing animals and can also be ingested by humans through the consumption of contaminated crops [9]. In addition to negative impacts on air quality and composition, incineration can also be relatively expensive. Alkaline hydrolysis uses sodium hydroxide or potassium hydroxide under heat and pressure to catalyze the hydrolysis of biological material. This process is carried out in a tissue digester consisting of an insulated, steam-jacketed, stainless-steel pressure vessel with a lid that is manually or automatically clamped [21]. Advantages of this technique of carcass disposal include simultaneous sterilization and digestion of the carcass, as well as the destruction of pathogens including prions. It further reduces waste by weight and volume by up to $97 \%$, and radioactive contaminants are eliminated [21]. However, alkaline hydrolysis is practiced offsite and presents biosecurity problems arising from the transport of infected animal carcasses from one area to a process plant [22]. A shortcoming of the process is the generation of large volumes of water as a by-product resulting from the use of alkali, high temperatures, and pressure to catalyze the hydrolysis of biological materials [23]. Therefore, research effort to develop more sustainable and environmentally friendly alternatives to carcass burial is required.

In this study, a mechanized thermo-chemical treatment system was developed to remediate burial sites by treating carcasses that had been buried. Dioxins and volatile organic compounds in the exhaust gas generated from the thermo-chemical treatment process were analyzed, and the chemical and biological properties of the thermo-chemically treated animal carcasses were analyzed. In order to investigate the possibility of using the thermo-chemically treated carcass as a substratum soil or fertilizer, lettuce was cultivated in low nutrient soil mixed with the treated carcass. Ammonia has been identified as a serious problem in the carcass burial sites [4], and the ammonia concentrations eluted from the thermo-chemically treated animal carcasses were analyzed. The addition of zeolite to the treated animal carcass was suggested to retard the elution of ammonia from the treated carcass and the efficiency was evaluated.

\section{Materials and Methods}

\subsection{Thermo-Chemical Treatment Machinery}

The process flow diagram for treating carcasses using thermo-chemical treatment is depicted in Figure 1. The raw materials comprising animal carcasses and quicklime were weighed and placed into a hopper. The carcasses were crushed two stages, using initial (coarse) crushing followed by secondary (fine) crushing. A mechanism using toothed counter blades that rotate past each other was used for crushing. Quicklime $(\mathrm{CaO})$ was mixed with the animal carcasses to absorb moisture. The input range for quicklime was $70-150 \%$ of the weight of the carcasses being treated. The number of animal carcasses and volume of quicklime was adjusted by controlling the rotation speed of the motor. After mixing the animal carcasses and quicklime, heat treatment was applied at high temperatures ranging from 200 to $500{ }^{\circ} \mathrm{C}$ in a rotary stirrer. After heat treatment, sawdust or coco peat was added (5-50\% weight of the carcasses) while the temperature was maintained at $100-150{ }^{\circ} \mathrm{C}$. Finally, the thermo-chemically treated carcass consisting of the ground carcasses, quicklime, and sawdust was ejected from the machine. The final product was 
weighed and packaged, then stored or transported for use as a soil fertilizer. The machinery for this series of processes was mounted and used on a motor vehicle (truck).
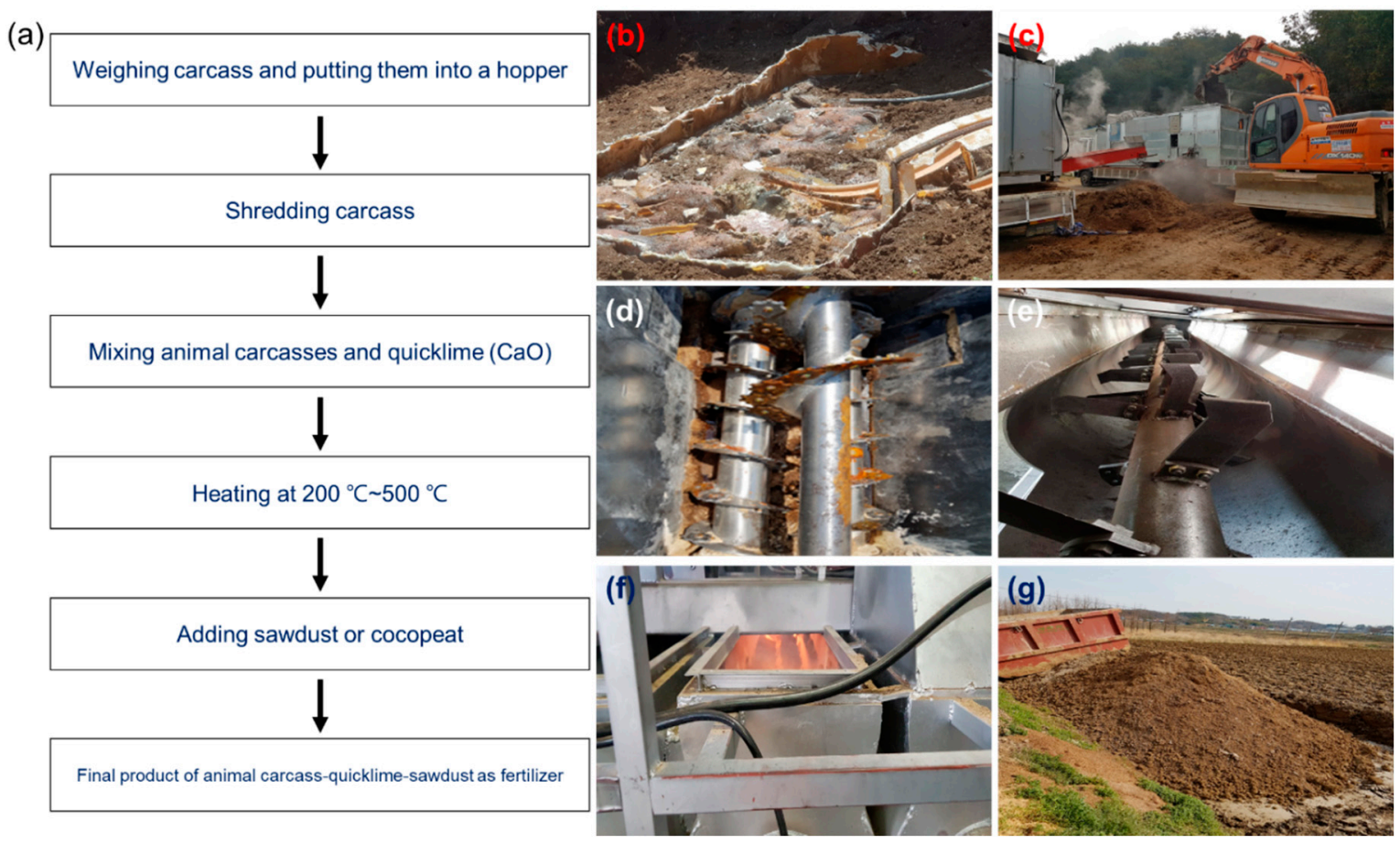

Figure 1. (a) Flow chart of the treatment process in thermo-chemical treatment machinery, (b) animal carcass buried in fiber-reinforced plastic before treatment, (c) placing a carcass into the hopper, (d) shredding carcass, (e) mixing the crushed product with quicklime, (f) heating to $200{ }^{\circ} \mathrm{C}$ to $500{ }^{\circ} \mathrm{C}$, (g) final product comprising animal carcass-quicklime-sawdust mixture for use as compost.

\subsection{Site Description}

Two livestock burial sites were remediated using the developed thermo-chemical treatment machinery to evaluate the field applicability of the machinery. A total of 16,000 chickens were buried in Buyeo-gun, Chungcheongnam-do, in January 2014, and remediation work was carried out for eight days using a mechanized thermo-chemical treatment system in November 2018. Similarly, 418 pigs were buried in March 2015 in Hongseong-gun, Chungcheongnam-do, and remediation work was carried out for ten days using a thermochemical treatment device in November 2018. The carcasses were buried in fiber-reinforced plastic containers to prevent secondary pollution from the burials.

\subsection{Gas Sampling and Analysis}

The gases emitted from the mechanized thermo-chemical treatment system were collected using a gas sampler with a 5 L Tedlar bag (SKC Inc., Eighty Four, PA, USA) at a flow rate of $100 \mathrm{~mL} / \mathrm{min}$. The concentrations of volatile organic compounds (VOCs) and dioxins were analyzed using a gas chromatography-mass spectrometry (GC-MS, GC/MSQP2010 Plus, Shimadzu, Japan) and atmospheric pressure gas chromatography with triple quadrupole mass spectrometry (APGC-MS/MS, Xevo TQ-XS, Waters, Milford, MA, USA, respectively.

\subsection{Chemical Analysis of the Treated Carcass Product}

Chemical properties of samples were analyzed according to Korean standard methods for the analysis of compost and soil chemistry. Nitrogen and carbon content was analyzed using an elemental analyzer (Flash-Smart, Thermo-Fisher, Waltham, MA, USA), and the quantified elements were then used to calculate the $\mathrm{C} / \mathrm{N}$ ratio. $\mathrm{P}_{2} \mathrm{O}_{5}$ was analyzed by the 
quimociac gravimetric method and $\mathrm{K}$ was analyzed using the sodium tetraphenylborate method. The moisture content of samples was quantified by measuring the loss of weight after $3 \mathrm{~h}$ at $130{ }^{\circ} \mathrm{C}$. For total heavy metal, $1 \mathrm{~g}$ of air-dried sample was digested using $8 \mathrm{~mL}$ of $\mathrm{HNO}_{3}$ and $2 \mathrm{~mL}$ of $\mathrm{HClO}_{4}$ at $140^{\circ} \mathrm{C}$ for $2 \mathrm{~h}$, and then the concentration for As, Cd, Cr, $\mathrm{Cu}, \mathrm{Ni}, \mathrm{Pb}$, and $\mathrm{Zn}$ was measured using an inductively coupled plasma optical emission spectroscope (ICP-OES, 5100, Agilent, Santa Clara, CA, USA). Na content for salinity was also measured using ICP-OES after the sample was mixed with deionized water. Compost maturity was determined by seed germination and the germination index using radish (Raphanus sativs L.) seeds, according to Ko et al. [24]. The alkali fraction was determined by the amount of $\mathrm{NaOH}$ added to titrate the $1 \mathrm{~g}$ of sample digested using $50 \mathrm{~mL}$ of $\mathrm{HCl}$. Escherichia coli O157:H7 was cultivated in mEC broth (tryptone $20 \mathrm{~g}$, bile salt $1.12 \mathrm{~g}$, lactose $5.0 \mathrm{~g}$, dipotassium phosphate $4.0 \mathrm{~g}$, monopotassium phosphate $1.5 \mathrm{~g}$, sodium chloride $5 \mathrm{~g}$, and DI water $1 \mathrm{~L}$ ). The bacteria identified as E. coli were used for O157 antiserum, and the bacteria identified as $\mathrm{O} 157$ were tested for H7 serotype. Salmonella bacteria were cultivated in peptone water (peptone $10 \mathrm{~g}$, sodium chloride $5 \mathrm{~g}$, DI water $1 \mathrm{~L}$ ) to identify their presence in the sample.

\subsection{Lettuce Growth Experiments Using Thermo-Chemically Treated Carcass as a Compost}

Lettuce growth experiments were conducted to test the feasibility of thermo-chemically treated carcass as compost, and the effects of buried soil samples on lettuce growth were evaluated by quantifying the leaf growth and weight of the mass of lettuce. Four different soil composition treatments were set up as follows: low nutrient soil alone, $75 \%$ of low nutrient soil and $25 \%$ of thermo-chemically treated carcass, $50 \%$ of low nutrient soil, and $50 \%$ of thermo-chemically treated carcass, and commercial soil for lettuce growth. The commercial soil was purchased from Korean local company (Samhwa Green Tech. Co., Korea) and it consisted of $74.84 \%$ coco peat, $15 \%$ vermiculite, $5 \%$ biotite, and $5 \%$ perlite. Lettuce was grown in $18 \mathrm{~cm}$-diameter pots and $14 \mathrm{~cm}$ in high pots; 27 pots were used for each set of conditions and, three seedlings were planted in each pot. Lettuce was grown in the greenhouse for 23 days and irrigated daily to maintain soil moisture for 20 min using mini overhead sprinklers. A total of 23 days after planting lettuce seedlings, the growth characteristics of the lettuce, including leaf length, leaf width, fresh weight, dry weight, number of leaves, and plant height were measured, and chlorophyll was measured using a chlorophyll measuring device (SPAD meter, Minolta Ltd., Tokyo, Japan). All characteristics except the weight were measured before drying. The dry weight was then measured after drying the samples at $100{ }^{\circ} \mathrm{C}$ for two days. The soil properties in the pots were also analyzed using the methods described in Section 2.4.

\subsection{Elution of Ammonia from the Treated Carcass Product}

Three sets of experiments were performed to investigate the effects of zeolite on retarding the release of $\mathrm{NH}_{4}{ }^{+}$from thermo-chemically treated carcass product. Elution experiments were performed by first agitating $5 \mathrm{~g}$ of the thermo-chemically treated product in $30 \mathrm{~mL}$ of deionized water at $100 \mathrm{rpm}$. The elution experiment water was sampled at $0.25,0.5,1,2,3,6,12$, and $24 \mathrm{~h}$, and was filtered through filter paper with $0.45 \mu \mathrm{m}$ of pore size. The $\mathrm{NH}_{4}$ concentration in the filtered sample was analyzed by the indophenol method using an UV spectrophotometer (Optizen POP QX, Mecasys Co., Daejeon, Korea) at $425 \mathrm{~nm}$. For the amendments using zeolite, two different ways, i.e., simultaneous and post addition of treated carcass, followed by extraction of $\mathrm{NH}_{4}$ from carcass separately were applied. For both experiments, $1 \mathrm{~g}$ of zeolite was applied to $30 \mathrm{~mL}$ of deionized water with $5 \mathrm{~g}$ of treated carcass product. These elution experiments were performed in triplicate. 


\subsection{Data Analysis}

Statistical analysis was performed for the data of lettuce growth and ammonia elution experiments using the SAS program (Version 9, SAS Institute, Cary, NC, USA). A oneway analysis of variance (ANOVA) was conducted to compare the means of the different treatments. When significant $F$-values were detected, the differences between individual means were tested using Duncan's multiple range tests.

\section{Results and Discussion}

\subsection{Gas Emitted from Thermo-Chemical Treatment Process}

The concentration of total VOC from the thermo-chemical treatment process was $430.3 \mathrm{\mu g} / \mathrm{m}^{3}$, while benzene was not detected. The concentrations of other VOCs including toluene, ethyl benzene, xylene, and styrene were $139.0,18.3,21.4$, and $10.4 \mu \mathrm{g} / \mathrm{m}^{3}$, respectively; these concentrations were all within the air pollutant emission standards issued by the Korean Ministry of Environment (toluene: 10 ppm; ethyl benzene: 23 ppm; xylene: $1 \mathrm{ppm}$; styrene: $23 \mathrm{ppm}$ ). The gas samples were analyzed for dioxins such as $2,3,7,8-$ TCDF, 2,3,7,8-TCDD, 1,2,3,7,8-PCDF, 2,3,4,7,8-PCDF, 1,2,3,7,8-PCDD, 1,2,3,4,7,8-HxCDF, 1,2,3,6,7,8-HxCDF, 2,3,4,6,7,8-HxCDF, 1,2,3,4,7,8-HxCDD, 1,2,3,6,7,8-HxCDD, 1,2,3,7,8,9HxCDD, 1,2,3,7,8,9-HxCDF, 1,2,3,4,6,7,8-HpCDF, 1,2,3,4,6,7,8-HpCDD, 1,2,3,4,7,8,9-HpCDF; none of these gases were detected.

\subsection{Characteristics of Thermo-Chemically Treated Carcass as a Compost}

The chemical properties of the thermo-chemically treated carcasses of chickens and pigs are provided in Table 1. As described in Section 2.2, we performed a feasibility test of thermo-chemical treatment machinery in the burial sites of both chickens and pigs. Two options, i.e., no addition of quicklime and the addition of quicklime were applied to treat the animal carcass. C, N, P, and heavy metals contents were similar between added and non-added quicklime, but lower germination index and higher alkali fraction were observed in the carcass treated with quicklime than without quicklime. The $\mathrm{N}$ and $\mathrm{C}$ contents of the thermo-chemically treated chicken carcass were lower than $\mathrm{N}(2.1-5.6 \%)$ and C (26.2-42.3\%) contents of composts obtained from poultry mortalities and litter [25]. The $\mathrm{N}$ content of the treated pigs in this study was higher than that $(0.71 \%)$ of pigs treated by $\mathrm{KOH}$ but much lower than that $(7.80 \%)$ of pigs treated by rendering process [2]. The $\mathrm{P}_{2} \mathrm{O}_{5}$ content of the treated pigs was also higher than that $(0.19 \%)$ treated by $\mathrm{KOH}$ [2]. The suitability of compost prepared via such processes was evaluated based on the Korean "Compost Process Standard Setting and Designation" Act. The N and C content in samples from pig carcasses was higher than in chicken carcasses. The $\mathrm{C}$ content, moisture content, and $\mathrm{C} / \mathrm{N}$ ratio for all samples were at appropriate levels. The concentrations of toxic trace metals including $\mathrm{Hg}, \mathrm{As}, \mathrm{Cd}, \mathrm{Pb}, \mathrm{Cu}, \mathrm{Ni}, \mathrm{Zn}$, and $\mathrm{Cr}$ were also within the required levels as per guidelines issued by the Korean government. The respective salinities of treated chicken and pig carcasses (both with and without quicklime) were also within the standard limits. Since E. coli (O157:H7) and Salmonella were not detected in all samples, it was determined that there was no biohazard concern. Despite satisfying all the above-mentioned criteria, the germination index was less than 70; the germination index criterion was thus not met. In order to increase the germination index value and use the treated animal carcass as compost, a composting process is essential after thermos-chemical treatment [24]. 
Table 1. Chemical properties of thermos-chemically treated carcass of chicken and pigs with Korean standard regulation for compost use.

\begin{tabular}{|c|c|c|c|c|c|}
\hline $\begin{array}{c}\text { Analysis } \\
\text { Items/Samples }\end{array}$ & Regulation & Chicken/No Quicklime & Chickens/Quicklime & Pigs/No Quicklime & Pigs/Quicklime \\
\hline $\mathrm{N}(\%)$ & & 0.74 & 0.80 & 0.91 & 1.00 \\
\hline $\mathrm{P}_{2} \mathrm{O}_{5}(\%)$ & & 0.27 & 0.34 & 0.30 & 0.38 \\
\hline K $(\%)$ & & 0.29 & 0.32 & 0.33 & 0.34 \\
\hline$C(\%)$ & $<12$ & 22.7 & 24.3 & 37.3 & 38.3 \\
\hline $\begin{array}{l}\text { Organic matter to } \\
\text { nitrogen ratio }\end{array}$ & $>45$ & 30.7 & 30.4 & 41.0 & 38.2 \\
\hline Moisture (\%) & $>85$ & 27.91 & 15.58 & 10.64 & 10.21 \\
\hline $\mathrm{Hg}(\mathrm{mg} / \mathrm{kg})$ & $>2$ & 0.00015 & 0.0076 & 0.004 & 0.0074 \\
\hline As $(\mathrm{mg} / \mathrm{kg})$ & $>45$ & 2.4 & 1.82 & 1.98 & 1.56 \\
\hline $\mathrm{Cd}(\mathrm{mg} / \mathrm{kg})$ & $>5$ & 0.12 & 0.12 & 0.12 & 0.16 \\
\hline $\mathrm{Pb}(\mathrm{mg} / \mathrm{kg})$ & $>130$ & 3.77 & 2.95 & 2.89 & 2.65 \\
\hline $\mathrm{Cu}(\mathrm{mg} / \mathrm{kg})$ & $>360$ & 5.79 & 5.21 & 9.71 & 10.54 \\
\hline $\mathrm{Ni}(\mathrm{mg} / \mathrm{kg})$ & $>45$ & 2.19 & 1.86 & 5.15 & 2.78 \\
\hline $\mathrm{Zn}(\mathrm{mg} / \mathrm{kg})$ & $>900$ & 30.88 & 24.77 & 60.5 & 61.28 \\
\hline $\mathrm{Cr}(\mathrm{mg} / \mathrm{kg})$ & $>200$ & 4.1 & 3.2 & 11.46 & 4.27 \\
\hline Salinity $(\%)$ & $>2$ & 0.22 & 0.23 & 0.23 & 0.24 \\
\hline Germination index & $<70$ & 30.98 & 19.74 & 24.27 & 17.83 \\
\hline Alkali fraction (\%) & & 16.07 & 25.18 & 12.7 & 25.51 \\
\hline $\begin{array}{c}\text { Escherichia coli } \\
\text { (O157:H7) }\end{array}$ & N.D ${ }^{+}$. & N.D. & N.D. & N.D. & N.D. \\
\hline Salmonella & N.D. & N.D. & N.D. & N.D. & N.D. \\
\hline
\end{tabular}

${ }^{\dagger}$ N.D. Not detected.

\subsection{Comparison of Thermo-Chemical Treatment Machinery with Conventional Methods}

Thermo-chemical treatment of carcasses is considered to be superior to other existing methods, both in terms of cost, processing time, and effectiveness. Dumping in open pits has been the most widely used method for disposal of carcasses in Korea, because Korean law requires disposal of dead livestock within $24 \mathrm{~h}$ to prevent the spread of infectious diseases [12]. However, burial/open pit disposal of carcasses can cause groundwater contamination via seepage, and hence the spread of disease-causing organisms. Another option for carcass disposal suggested by the Korean government is incineration, but its application has been limited because of the risk of spread of infectious diseases during transportation and backlogs owing to insufficient incinerator capacity [3]. Incineration also involves high running costs (including labor) and generates offensive odors and air pollution [26]. In recent years, rendering processes have proven advantageous because the production process is safe and can be used for an additive for animal feeding because of the high protein content. However, the rendering process is costly and energy-intensive; it can furthermore lead to the spread of pathogenic microorganisms during transportation of carcasses to rendering plants $[27,28]$.

For the current study, since the thermo-chemical treatment method was carried out at a lower temperature than required for incineration, the residence time was brief and processing speed was rapid. It was determined that the thermo-chemical treatment method can be conducted faster than other methods (apart from burial). While it required 10 days to treat 418 pigs using thermo-chemical treatment machinery, for incineration, rendering, and anaerobic digestion processes it would take more than 20 days. As described in Section 3.2, dioxins and VOCs that are commonly emitted during incineration were not detected or were observed to be below the acceptable limit. Despite the rapid treatment, no biohazards such as E. coli and Salmonella were detected on carcasses treated using the mechanized thermo-chemical treatment process. Another advantage of the latter process is that having the equipment affixed to a truck provides the mobility to treat carcasses on site. This can reduce the risk of spread of disease from transporting infected carcasses. The 
return of treated animal carcasses back to the soil is a particularly valuable method, unlike incineration, in terms of the circulation of carbon and nutrients.

To be widely adopted in the field, the cost of operation should also be considered. The cost for the two cases covered in the field study is analyzed in Table 2. Income is the amount contracted with local governments for the remediation of burial sites. The total cost of treating 418 pigs' carcasses was higher than for treating 16,000 chickens. The largest cost was the rental of equipment such as excavators and dump trucks. This was followed by the cost of purchasing consumable materials such as sawdust and quicklime. The benefit/cost ratios for treating 16,000 chickens and 418 pigs were 4.24 and 2.92, respectively. The total cost of manufacturing the mechanized thermo-chemical treatment unit was 170,000,000 KRW (=141,667 USD). The thermo-chemical treatment method was thus remarkably economical, even when considering depreciation in the value of the machinery. The costs for treating one ton of chicken and pigs were 548 USD and 754 USD, respectively, which were higher than that of burial (200 USD), landfill usage (500 USD), and aerobic digestion (125 USD) but less than that of fixed-facility incineration (2000 USD) [15,29]. Considering the land use and time efficiency, the thermo-chemical treatment method has advantages over other methods.

Table 2. Economic analysis for treating buried chickens and pigs using thermo-chemically treatment system. Unit: KRW.

\begin{tabular}{ccc}
\hline Classification & $\mathbf{1 6 , 0 0 0}$ Chickens/8 Days & 418 Pigs/10 Days \\
\hline Income & $67,042,000$ & $110,724,000$ \\
Total cost & $15,791,050$ & $37,835,315$ \\
Labor costs & $1,170,000$ & $5,700,000$ \\
Equipment rental fee & $6,248,500$ & $12,881,000$ \\
Consumable material cost & $4,378,500$ & $6,920,000$ \\
Cost estimates per ton of carcass disposal & 548 & 754 \\
(USD/ton) & & \\
\hline
\end{tabular}

\subsection{Lettuce Growth Using Thermo-Chemically Treated Carcass Product as a Compost}

Statistical analyses of the plant height, leaf length, leaf width, fresh weight, dry weight, number of leaves, and chlorophyll content are described in Table 3. Except for chlorophyll content, all characteristics of lettuce at 23 days after cultivation were statistically significant. These latter parameters for lettuce grown in low nutrient soil alone were significantly larger than lettuce grown in all soils mixed with thermo-chemically treated carcass product, regardless of mixing ratio, indicating that the addition of thermo-chemically treated carcass to the soil inhibited the growth of lettuce. These results indicate that the addition of treated carcass product to the soil did not aid the growth of lettuce because the nutrients in uncomposted form were not available for uptake in the soil and thus could not provide nutrients to the lettuce. Nutrients such as $\mathrm{N}$ and $\mathrm{P}$ should be mineralized to be used as a source of nutrients for plant growth through composting processes [30]. Table 4 shows that higher N, P, and K content was observed in the soil amended with treated carcass product; this result also supports the assertion that the nutrients from the treated carcass were not available for lettuce growth, even at higher concentrations. Thus to use thermochemically treated carcasses as compost or substrate soil for plant cultivation, a subsequent composting process is required. 
Table 3. Growth properties of lettuce cultivated under three different conditions, i.e., nutrient-poor soil and commercial soil amended with $0 \%, 25 \%$, and $50 \%$ of treated carcass product, respectively.

\begin{tabular}{|c|c|c|c|c|c|c|c|}
\hline $\begin{array}{c}\text { Treated Carcass } \\
\text { Addition (\%) }\end{array}$ & $\begin{array}{l}\text { Plant Height } \\
(\mathrm{mm})\end{array}$ & $\begin{array}{l}\text { No. of } \\
\text { Leaves }\end{array}$ & $\begin{array}{l}\text { Leaf Length } \\
\text { (mm) }\end{array}$ & $\begin{array}{l}\text { Leaf Width } \\
\quad(\mathrm{mm})\end{array}$ & $\begin{array}{c}\text { Fresh } \\
\text { Weight (g) }\end{array}$ & Dry Weight (g) & Chlorophyll \\
\hline $0 \%$ & $158.1 \pm 6.7 b^{z}$ & $67+02$ & $112.3 \pm 5.2 b$ & $41.1 \pm 1.2 \mathrm{~b}$ & $2325+03 \mathrm{~h}$ & & \\
\hline $25 \%$ & $132.3 \pm$ & $6.5 \pm$ & 9 & $6 c$ & $289 \pm$ & bc & $0.9 \mathrm{~b}$ \\
\hline $50 \%$ & $134.8 \pm 2.6 c$ & $6.6 \pm 0.1 b$ & $92.9 \pm 2.2 c$ & $34.4 \pm 0.7 c$ & $2.055 \pm 0.1 b$ & $0.246 \pm 0.01 \mathrm{c}$ & $25.4 \pm 0.3 \mathrm{ab}$ \\
\hline $\begin{array}{l}\text { Commercial soil } \\
\text { Significance }\end{array}$ & $\underset{* * *}{307.1 \pm} 6.9 \mathrm{a}$ & $\underset{* * *}{7.8 \pm 0.2 \mathrm{a}}$ & $\underset{* * *}{167.8 \pm 4.6 \mathrm{a}}$ & $49.1 \underset{* * *}{ \pm 0.8} \mathrm{a}$ & $\underset{* * *}{8.915 \pm 0.8 \mathrm{a}}$ & $\underset{* *}{0.420 \pm 0} \pm 0.04 \mathrm{a}$ & $\begin{array}{c}25.4 \pm 0.2 \mathrm{ab} \\
\mathrm{ns}\end{array}$ \\
\hline
\end{tabular}

${ }^{\mathrm{z}}$ Mean separation within columns by Duncan's multiple range test at $p=0.05$. ns, ${ }^{* * *},{ }^{* * *}$ Non-significance or significance at $p \leq 0.05$, or 0.001 , respectively. $a, b, c$ Different letters indicate statistical differences.

Table 4. Properties of nutrient-poor soil amended with $0 \%, 25 \%$, and $50 \%$ treated carcass product.

\begin{tabular}{cccc}
\hline Treated Carcass Addition (\%) & $\mathbf{0 \%}$ & $\mathbf{2 5 \%}$ & $\mathbf{5 0 \%}$ \\
\hline $\mathrm{N}(\%)$ & 0.019 & 0.059 & 0.120 \\
$\mathrm{P}_{2} \mathrm{O}_{5}(\%)$ & 0.006 & 0.081 & 0.024 \\
$\mathrm{~K}(\%)$ & 0.055 & 0.320 & 0.060 \\
$\mathrm{C}(\%)$ & 4.99 & 6.10 & 8.28 \\
Organic matter to nitrogen ratio & 262.7 & 103.4 & 8.28 \\
Moisture (\%) & 24.82 & 26.66 & 32.47 \\
Salinity (\%) & 0.058 & 0.096 & 0.062 \\
Decomposed degree(germination) & 91.38 & 97.68 & 95.09 \\
Alkali fraction (\%) & 0.91 & 2.2 & 0.98 \\
E. coli (O157:H7) & N.D. & N.D. & N.D. \\
Salmonella & N.D. & N.D. & N.D. \\
\hline
\end{tabular}

\subsection{Application of Zeolite for Retarding the Release of $\mathrm{NH}_{4}$ from Treated Carcass Product}

$\mathrm{NH}_{4}$ concentrations eluted from the treated carcass product in the presence and absence of zeolite are shown in Figure 2. Statistical analysis was also performed to investigate the effect of zeolite amendment and elution time on $\mathrm{NH}_{4}$ elution from the treated carcass, and the results are provided in Table 5. The ANOVA results showed that both zeolite treatment and reaction time significantly $(p<0.0001)$ influenced $\mathrm{NH}_{4}$ concentration eluted from the treated carcass. Because the treated carcass product did not undergo a composting process, $\mathrm{NH}_{4}$ was not mineralized to $\mathrm{NO}_{3}$ and therefore, there were high levels of $\mathrm{NH}_{4}$ present [31]. The $\mathrm{NH}_{4}$ concentration rapidly (within $15 \mathrm{~min}$ ) rose to $32.5 \mathrm{mg} / \mathrm{L}$, thereafter it slowly increased to $44.6 \mathrm{mg} / \mathrm{L}$ in $3 \mathrm{~h}$. When the zeolite was added to the solution after reacting with the treated carcass for $24 \mathrm{~h}$. The $\mathrm{NH}_{4}$ concentration initially decreased to $5.5 \mathrm{mg} / \mathrm{L}$ but increased again to $7.4 \mathrm{mg} / \mathrm{L}$ at $24 \mathrm{~h}$. With zeolite, the average concentration of $\mathrm{NH}_{4}$ was $5.7 \mathrm{mg} / \mathrm{L}$, representing a decrease of $87.9 \%$. These results show that the addition of zeolite resulted in adsorption of $\mathrm{NH}_{4}$; zeolite was therefore effective in retarding the release of $\mathrm{NH}_{4}$ from the treated carcass. When the zeolite was added to treated carcass in solution, the $\mathrm{NH}_{4}$ concentration gradually increased to $8.4 \mathrm{mg} / \mathrm{L}$ by $3 \mathrm{~h}$, thereafter it decreased to $6.7 \mathrm{mg} / \mathrm{L}$. The initial increase of $\mathrm{NH}_{4}$ concentration was consistent with the maximum eluted $\mathrm{NH}_{4}$ concentration from the treated carcass, as observed after $3 \mathrm{~h}$. 

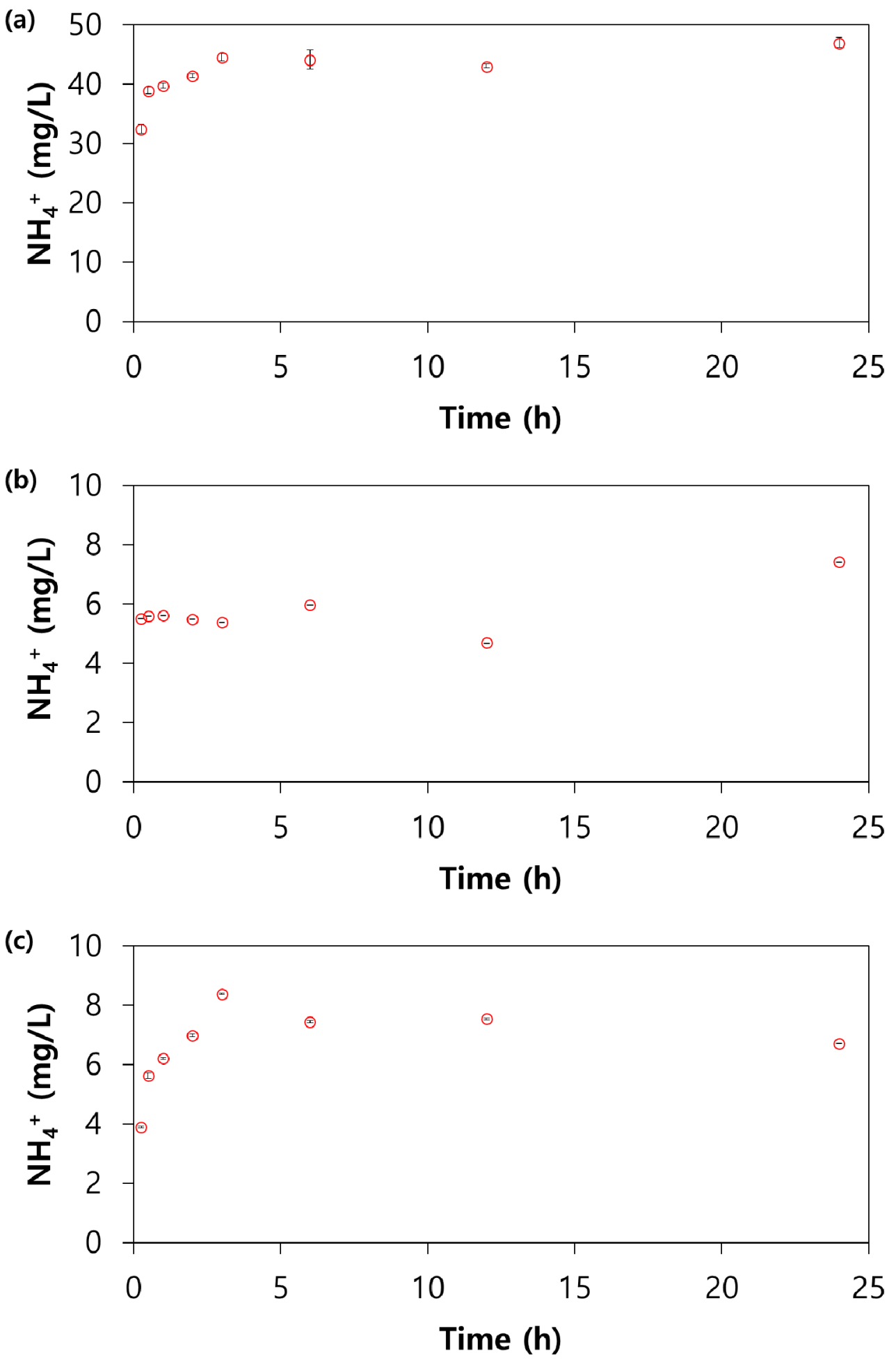

Figure 2. Reaction time for $\mathrm{NH}_{4}$ concentration eluted from thermo-chemically treated carcass product. (a) non-treated condition, (b) zeolite added after $\mathrm{NH}_{4}$ elution from thermo-chemically treated carcass product over a $24 \mathrm{~h}$ period, and (c) thermo-chemically treated carcass and zeolite in the same solution.

Zeolite can adsorb $\mathrm{NH}_{4}{ }^{+}$ions in aqueous solution through cation exchange by replacing exchangeable cations adsorbed on the framework, formed from $\mathrm{SiO}_{4}$ and $\mathrm{AlO}_{4}$ tetrahedra of zeolite [31,32]. The anions adsorbed via cation exchange are loosely held together by electrostatic attraction, and they can diffuse into a solution after replacement by other anions [33]. Zeolite plays an important role in supplying $\mathrm{NH}_{4}$ by reducing leaching of 
$\mathrm{NH}_{4}$ via water infiltration and volatilizing $\mathrm{NH}_{4}$ as the form of $\mathrm{NH}_{3}$ at high $\mathrm{pH}$. Therefore, the addition of zeolite helps provide $\mathrm{NH}_{4}$ to plants at a slower rate over a longer period.

Table 5. ANOVA for $\mathrm{NH}_{4}$ concentrations eluted from the treated carcass with regard to zeolite amendment and elution time.

\begin{tabular}{cccccc}
\hline Source & DF & Sum of Squares & Mean Square & $\boldsymbol{F}$ Value & $\operatorname{Pr}>\boldsymbol{F}$ \\
\hline Sol & 2 & $19,724.2$ & 9862.1 & 3691.4 & $<0.0001$ \\
Time & 7 & 268.8 & 38.4 & 14.4 & $<0.0001$ \\
Sol-Time & 14 & 265.4 & 18.9 & 7.1 & $<0.0001$ \\
\hline
\end{tabular}

\section{Conclusions}

The mechanized thermo-chemical treatment process developed in this study treats animal carcasses sequentially. The process includes crushing, quicklime amendment and mixing, heat treatment $\left(200-500{ }^{\circ} \mathrm{C}\right)$, sawdust amendment and mixing, and ejection. Compared to incineration, rendering, and anaerobic digestion, the thermo-chemical treatment method has the advantages of rapid treatment of carcasses as well as no secondary pollution such as soil and groundwater contamination associated with livestock burial. Since the device is mounted on a truck and moved to the field to treat the carcass, the risk of the spread of disease from transportation is avoided. Dioxins (a problem during incineration) were not detected, and the concentration of VOCs was within the air pollutant emission standards. The mechanized thermo-chemical treatment process was applied to treat the carcasses of chickens and pigs buried in the storages of fiber-reinforced plastics. The thermo-chemical treatment method for treating the carcass in burial sites is economical with high benefit/cost ratios. The legal criteria for compost such as heavy metal concentration, the contents of C, N, and P, and the absence of E. coli and Salmonella were satisfied, but the germination index was not suitable. Owing to its low germination index, when the treated carcass product was used to compost low nutrient soil, lettuce growth was poorer than in low nutrient soil without the treated carcass. The use of zeolite was suggested for adsorbing ammonia, which was identified as an important pollutant in the burial site. Since zeolite was effective in adsorbing the ammonia eluted from the treated carcass, nitrogen can be more effectively supplied to plants by adding zeolite to the product before it is used to amend the soil. Mechanized thermo-chemical treatment processing is an excellent technique for treating animal carcasses, although composting of the product is required before it is used to amend the soil for plant growth.

Author Contributions: Conceptualization, S.-J.P. and D.-H.K.; methodology, J.-I.L. and E.-J.C.; validation, J.-I.L.; formal analysis, J.-I.L. and E.-J.C.; data curation, J.-I.L. and C.-H.L.; visualization, S.-Y.H.; supervision, S.-J.P. and C.-G.L.; writing-original draft preparation, J.-I.L., F.N.L., and S.-J.P.; writing-review and editing, S.-J.P. and C.-G.L. All authors have read and agreed to the published version of the manuscript.

Funding: This work was also supported by Korea Institute of Planning and Evaluation for Technology in Food, Agriculture, Forestry, and Fisheries through Animal Disease Management Technology Development Program, funded by MAFRA (Grant No. 118095-2).

Institutional Review Board Statement: Not applicable.

Informed Consent Statement: Not applicable.

Data Availability Statement: The data presented in this study are available on request from the corresponding author. The data are not publicly available due to that this study was conducted with financial support from the Korean government.

Conflicts of Interest: The authors declare no conflict of interest. 


\section{References}

1. Delgado, C.; Rosegrant, M.; Steinfeld, H.; Ehui, S.; Courbois, C. Livestock to 2020; International Food Policy Research Institute: Washington, DC, USA, 1999.

2. Seo, D.C.; Kang, S.-W.; Choi, I.-W.; Sung, H.-H.; Hur, T.-Y.; Yoo, J.-Y.; Lee, Y.-J.; Heo, J.S.; Kang, S.-J.; Cho, J.-S. Evaluation of Fertilizer Value of Animal Cadavers for Agricultural Recycling. Korean J. Soil Sci. Fertil. 2011, 44, 788-793. [CrossRef]

3. Kim, G. Treatment of residues of excavated carcasses burials. J. Korean Soc. Water Wastewater 2018, 32, 269-277. [CrossRef]

4. Chowdhury, S.; Kim, G.-H.; Bolan, N.; Longhurst, P. A critical review on risk evaluation and hazardous management in carcass burial. Process. Saf. Environ. Prot. 2019, 123, 272-288. [CrossRef]

5. Yuan, Q.; Snow, D.; Bartelt-Hunt, S. Potential water quality impacts originating from land burial of cattle carcasses. Sci. Total. Environ. 2013, 456, 246-253. [CrossRef] [PubMed]

6. Vanier, M.; Comer, P.; Hater, G.; Kaye, G.; Meeker, D.; Thacker, H. Ruminant Carcass Disposal Options for Routine and Catastrophic Mortality; Council for Agricultural Science and Technology (CAST): Ames, IA, USA, 2009; p. 41.

7. Nutsch, A.; Spire, M. Carcass Disposal: A Comprehensive Review; National Agricultural Biosecurity Center, Kansas State University: Manhattan, KS, USA, 2004; Chapter 1.

8. Freedman, R.; Fleming, R. Water Quality Impacts of Burying Livestock Mortalities; Livestock Mortality Recycling Project Steering Committee: Ridgetown, ON, Canada, 2003.

9. Gwyther, C.L.; Williams, A.P.; Golyshin, P.N.; Edwards-Jones, G.; Jones, D.L. The environmental and biosecurity character-istics of livestock carcass disposal methods: A review. Waste Manag. 2011, 31, 767-778. [CrossRef] [PubMed]

10. Glanville, T. Impact of livestock burial on shallow groundwater quality. In Proceedings of the American Society of Agri-Cultural Engineers, Mid-Central Meeting, St. Joseph, MI, USA, 28 April 2000.

11. Myers, L.M.; Bush, P.B.; Segars, W.; Radcliffe, D.E. Impact of Poultry Mortality Pits on Farm Groundwater Quality. In Proceedings of the 1999 Georgia Water Resources Conference, Athens, Georgia, 30-31 March 1999.

12. Kim, K.H.; Kim, K.R.; Kim, H.S.; Lee, G.T.; Lee, K.H. Assessment of soil and groundwater contamination at two animal car-cass disposal sites. Korean J. Soil Sci. Fert. 2010, 43, 384-389.

13. Davies, R.H.; Wray, C. Seasonal variations in the isolation of Salmonella typhimurium, Salmonella enteritidis, Bacillus ce-reus and Clostridium perfringens from environmental samples. J. Vet. Med. B 1996, 43, 119-127. [CrossRef] [PubMed]

14. Det Norske Veritas. Independent Environmental and Public Health Risk Assessment of DEFRA Foot and Mouth Disease Disposal Site; No. 20073900; Det Norske Veritas: Oslo, Norway, 2003.

15. McClaskey, J.M. A Multidisciplinary Policy Approach to Food and Agricultural Biosecurity and Defense. Ph.D. Thesis, Kansas State University, Manhattan, KS, USA, 2014.

16. Mukhtar, S.; Kalbasi, A.; Ahmed, A. Carcass Disposal: A Comprehensive Review; National Agricultural Biosecurity Center, Kansas State University: Manhattan, KS, USA, 2004; Chapter 3.

17. Auvenmann, B.; Kalbasi, A.; Ahmed, A. Carcass Disposal: A Comprehensive Review; National Agricultural Biosecuity Center, Kansas State University: Manhattan, KS, USA, 2004; Chapter 4.

18. Kalbasi-Ashtari, A.; Schutz, M.; Auvermann, B. Carcass rendering systems for farm mortalities: A review. J. Environ. Eng. Sci. 2008, 7, 199-211. [CrossRef]

19. Staroń, P.; Kowalski, Z.; Staroń, A.; Banach, M. Thermal treatment of waste from the meat industry in high scale rotary kiln. Int. J. Environ. Sci. Technol. 2017, 14, 1157-1168. [CrossRef]

20. Chen, S.-J.; Hung, M.-C.; Huang, K.-L.; Hwang, W.-I. Emission of heavy metals from animal carcass incinerators in Taiwan Chemosphere 2004, 55, 1197-1205. [CrossRef] [PubMed]

21. Thacker, H.L. Carcass Disposal: A Comprehensive Review; National Agricultural Biosecurity Center, Kansas State University: Manhattan, KS, USA, 2004; Chapter 6.

22. Erickson, L.E.; Fayet, E.; Kakumanu, B.K.; Davis, L.C. Carcass Disposal: A Comprehensive Review; National Agricultural Biosecurity Center, Kansas State University: Manhattan, KS, USA, 2004; Chapter 5.

23. Arias, J.Z.; Reuter, T.; Sabir, A.; Gilroyed, B.H. Ambient alkaline hydrolysis and anaerobic digestion as a mortality management strategy for whole poultry carcasses. Waste Manag. 2018, 81, 71-77. [CrossRef] [PubMed]

24. Ko, H.J.; Kim, K.Y.; Kim, H.T.; Kim, C.N.; Umeda, M. Evaluation of maturity parameters and heavy metal contents in com-posts made from animal manure. Waste Manag. 2008, 28, 813-820. [CrossRef] [PubMed]

25. Cummins, C.G.; Wood, C.W.; Delaney, D.P. Co-Composted Poultry Mortalities and Poultry Litter. J. Sustain. Agric. 1994, 4, 7-19. [CrossRef]

26. Donald, J.O.; Blake, J.P. Dead poultry composter construction. In Proceedings of the 1990 National Poultry Waste Management Symposium. National Poultry Waste Management Symposium Committee, Raleigh, NC, USA, 3-4 October 1990; p. 384.

27. Poss, P.E. Central pick-up of farm dead poultry. In Proceedings of the 1990 National Poultry Waste Management Symposium. National Poultry Waste Management Symposium Committee, Raleigh, NC, USA, 3-4 October 1990; pp. 75-76.

28. CAST (Council for Agricultural Science and Technology). Swine Carcass Disposal Options for Routine and Catastrophic Mortality; CAST: Ames, IA, USA, 2009; p. 39.

29. McClaskey, J. Carcass Disposal: A Comprehensive Review; National Agricultural Biosecurity Center, Kansas State University: Manhattan, KS, USA, 2004; Chapter 9. 
30. Bernal, M.P.; Sommer, S.G.; Chadwick, D.; Qing, C.; Guoxue, L.; Michel, F.C., Jr. Current approaches and future trends in compost quality criteria for agronomic, environmental, and human health benefits. Adv. Agron. 2017, 144, 143-233.

31. Leyva-Ramos, R.; Jacobo-Azuara, A.; Diaz-Flores, P.; Guerrero-Coronado, R.; Mendoza-Barron, J.; Berber-Mendoza, M. Adsorption of chromium(VI) from an aqueous solution on a surfactant-modified zeolite. Colloids Surf. A Physicochem. Eng. Asp. 2008, 330, 35-41. [CrossRef]

32. Hong, S.-H.; Lee, J.-I.; Lee, C.-G.; Park, S.-J. Effect of temperature on capping efficiency of zeolite and activated carbon under fabric mats for interrupting nutrient release from sediments. Sci. Rep. 2019, 9, 1-11. [CrossRef] [PubMed]

33. Brady, N.C.; Weil, R.R. Elements of the Nature and Properties of Soils, 3rd ed.; Pearson Prentice Hall: Upper Saddle River, NJ, USA, 2014. 